\title{
Proposal for Environmental Interpretation at the Santa Barbara Chapel (Ponta Grossa, PR)
}

\author{
Beatriz Madalena Bueno Da Silvaa; \\ Mirna De Lima Medeirosb; \\ Silvielen Cristiane Faria De Larac; \\ Eduardo Vitor Correa de Souzad
}

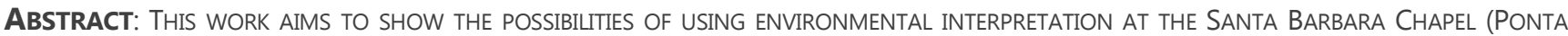
Grossa, State of ParanÁ). This chapel, built in 1823, was listed in 2000 by the Municipal Council of Cultural Heritage, however MANY PEOPLE, INCLUDING RESIDENTS, DO NOT KNOW MUCH ABOUT IT. TO THIS END, WE SOUGHT TO ANALYSIS ITS POTENTIAL STATUS AS A TOURIST ATTRACTION; TO VERIFY THE APPLICATIONS OF ENVIRONMENTAL INTERPRETATION; AND TO SUGGEST ACTIONS OF ENVIRONMENTAL INTERPRETATION THAT CAN BE PERFORMED IN RELATION TO THE HERITAGE, FOCUSING ON THE APPRECIATION OF ITS HISTORY. THE THEORETICAL FRAMEWORK DEFINES THE CONCEPT OF ENVIRONMENTAL INTERPRETATION AND ITS TOOLS, AND ADDRESSES THE HISTORY OF THE CHAPEL AND THE SAINT WHOSE NAME IT CARRIES. DESCRIPTIVE RESEARCH WAS USED TO COMPILE DATA, USING DOCUMENTARY RESEARCH AND DIRECT OBSERVATION IN ON-SITE FIELDWORK. THE POTENTIAL FOR THE APPLICATION OF ENVIRONMENTAL INTERPRETATION AT THE SANTA BARBARA CHAPEL WAS VERIFIED, WHETHER TO TRANSMIT BASIC AND HISTORICAL INFORMATION THROUGH AN INTERPRETATIVE PANEL, OR THROUGH THE EXPANSION OF THE EXPERIENCE THROUGH A PROPERTY -GUIDED NARRATIVE, FOR EXAMPLE.
\end{abstract}

\section{KEYWORDS}

Cultural Tourism;

Environmental Interpretation;

Heritage;

Santa Barbara Chapel; 


\section{INTRODUCTION}

Environmental interpretation can serve as a tool for keeping the history and memory of a place alive, while providing an enriching experience for visitors, as it "must be pleasurable, differentiated, provocative and meaningful" (Tilden, 1977 apud Ambiental, 2003, p. 19). It has broad applicability, but it is observed more in natural areas.

The Santa Barbara Chapel was built in 1823 on land donated to a group of Jesuits in Ponta Grossa (PR). Due to its significant historical value, the chapel was listed in 2000 by the COMPAC (Municipal Council of Cultural Heritage). Despite its historical and cultural value, the attraction is in last place among the "city attractions" listed in a social network focusing on travel. Among the three comments on this social network (April 2019), one states that: "It is good to go with a guide, because without the historical information, it's not even worth going, because it is a small building that has a lot of meaning in the history of the municipality. "

Thus, the research question of this paper was: How could environmental interpretation be implemented at the Santa Barbara Chapel? and the overall objective of this paper was: to discuss how environmental interpretation could be implemented in the Santa Barbara Chapel. To this end, the following objectives were set: to analyze its potential status as a tourist attraction through a diagnosis; to verify the applications of environmental interpretation; and to suggest actions of environmental interpretation that can be performed in relation the heritage, focusing on the appreciation of its history.

The research is justified through its important interface with the community. Although we do not propose to carry out any actions (which require resources), this analysis of the improvements needed to enhance and preserve the space, increasing its quality and attractiveness, may be useful for public and private managers. This study also promotes the preservation of the history of the first chapel to be built in Ponta
Grossa, and suggests an interpretation focused on heritage as a means of enhancing its perception of value. The article begins with the theoretical framework, showing how the authors define environmental interpretation. It then goes on to present the topic of interpretation focused on heritage, and the necessary tools for the interpretation, followed by the methodology used. The results and discussions section presents the characterization of the study site and the history of the Santa Barbara Chapel and the Saint to which it is dedicated. It also presents site diagnostics and suggestions for interpretation tools that could be used on the property. At the end, some final considerations are given, and references used are listed.

\section{ENVIRONMENTAL INTERPRETATION \& TOURISM}

Karina Souza (2010) mentions that Tilden (1977) was the first to express the concept of environmental interpretation. According to Freeman Tilden (2006, p.19 apud Souza, 2010) it is "an activity of an essentially educational character, but less erudite and scientific". Environmental interpretation is defined as an educational activity with thematic, organized, meaningful, provocative, differentiated and pleasant characteristics (Ambiental, 2002).

For Tilden (1977, apud Ambiental, 2002, p. 13) there are two concepts for interpretation: "The first of these is for the interpreter himself and the second for contact with his audience. The concept for the interpreter says, "interpretation is the revelation of a great truth that lurks behind simple manifestations." The second, for his contact with his audience, states, "interpretation must capitalize on the visitor's simple curiosity for the enrichment of his mind and spirit."

For Siqueira (2004), who focuses specifically on ecotourism trails, environmental interpretation, besides being a flexible educational technique, seeks to convey information to a certain audience through an appropriate and easily understood language. Also according to the author, it can also bring understanding about anthropic phenomena and their interactions with natu- 
ral environments. Moreira (2014, p. 78), who also deals with natural areas, considers environmental interpretation to be "a part of environmental education, being the term used to describe the activities of a communication made for a better understanding of the natural environment in protected areas. " It serves as an important tool for transmitting to visitors experiences of direct contact with nature, and making them aware of environmental issues (Silva \& Júnior, 2010).

Chaverri (1988 apud UNIT, 2005) broadens this definition of interpretation by pointing out that it can be understood as art, and at the same time, as a form of human communication that explains to the visitor the characteristics of the environment. It can refer not only to the natural environment but also so be applied to museums and historic cities, for example. Environmental interpretation is related to the experiences that tourists have when visiting that place.

Complementing Tilden (1977 apud Environmental, 2002), it is pointed out that interpretation is an educational activity that shows, through the use of objects, the direct relationship with resources and illustrative means, instead of transmitting information in its full sense. It should be noted that environmental interpretation and environmental education are distinct concepts. According to Medeiros (2018), environmental education aims to rescue certain educational values and objectives in order to value environmental knowledge (in formal, non-formal or informal spaces of education) and can be considered as a political, pedagogical and scientific movement aimed at educational reform.

Given the above, it is understood that the authors have similar views on the definition of environmental interpretation, and that this tool can be applied to both natural and man-made areas. Thus, it may be present in a built heritage, as a way of interpreting the heritage.

According to the Institute of National Historical and Artistic Heritage (IPHAN, 2014), heritage is defined as: "A set of movable and immovable property existing in the country and whose conservation is of public inte- rest, either because of its link to memorable facts of the history of Brazil, or for its exceptional archaeological or ethnographic, bibliographic or artistic value."

IPHAN links the cultural heritage with the history of the place, whether it is associated with parents, grandparents, or even earlier than that. It should be important to many people, as a place that many find relevant, a shared history or a building (Florêncio, 2016). In view of this, the interpretation of heritage adds value to the tourist experience, stimulating the environmental appreciation through the available information, highlighting the history of the heritage and causing the visitor to no longer be a stranger and at that moment of the visit, feel that he or she is part of the place (Murta \& Albano, 2002). In addition to "investigating, restoring, conserving and interpreting heritage, it is sometimes necessary to resort to other strategies that facilitate tourism." And with that, increase its attractiveness and turn heritage into a product (Biesek, 2004, p. 47).

According to Delgado (2013, p. 319) heritage interpretation is an "instrument for introducing criteria of environmental quality and sustainability in tourism planning". Tilden (2006, p. 119 apud Delgado, 2013, p. 308) argues that: "It is essential that in the context of interpretation, participation is physical. If you try to include everything that is completely or predominantly mental, the words begin to lose their meaning. Not only must it imply a physical act, it must also be something that the participant himself considers new, special and important to himself".

According to Vasconcellos (1998) people don't only seek teachings and readings when visiting a place; they must also be involved in pleasant ways, creating a new understanding of the place through environmental interpretation. Given the views of the authors Delgado (2013), Murta \& Albano (2012), Biesek (2004) and Vasconcellos (1998) about heritage interpretation, environmental heritage-oriented interpretation can be seen as a tool to improve the visitor's knowledge and relationship with the environment. 
For the environmental interpretation of the heritage to occur easily, means are needed to facilitate the process, mitigate the impacts caused by visitors, and increase their awareness of its importance. According to Ambiental (2002, p. 52), the chosen tools should be consistent with the general planning of the property.

There are several types of instruments used in environmental interpretation. Table 1 shows some of the tools that exist, and that are currently used in parks, protected areas, and built heritage sites. These tools can be used alone or in combination, and each has their own characteristics and costs to be considered in the decision-making process.

Table 1: Tools for Environmental Interpretation.

\begin{tabular}{|c|c|}
\hline \multicolumn{2}{|c|}{ Tools for Environmental Interpretation } \\
\hline Mock-ups & $\begin{array}{l}\text { Creating a mock-up combines } \\
\text { exhibits with graphic media and } \\
\text { historical places. The visitor can } \\
\text { analyze these items at their own } \\
\text { pace, while looking at the mock- } \\
\text { up. The maintenance cost is low. } \\
\text { The model can be made with } \\
\text { recyclable materials to reduce } \\
\text { costs. }\end{array}$ \\
\hline Lectures & $\begin{array}{l}\text { Lectures can be given by outsid- } \\
\text { ers, as special guests or by } \\
\text { someone who already works at } \\
\text { the heritage site. Having invited } \\
\text { guests can make up for a short- } \\
\text { fall of on-site guides, or gaps in } \\
\text { their knowledge. Lectures can be } \\
\text { supported by movies or slides } \\
\text { that help complete the environ- } \\
\text { mental interpretation. }\end{array}$ \\
\hline $\begin{array}{l}\text { Signboards and } \\
\text { Panels }\end{array}$ & $\begin{array}{l}\text { The use of signboards, panels, } \\
\text { and stationary texts is mostly } \\
\text { used on trails, but they can also } \\
\text { be used to cost-effectively con- } \\
\text { vey information to visitors. For } \\
\text { Murta \& Albano (2002) placing a } \\
\text { "welcome" sign pleases visitors } \\
\text { as they enter. }\end{array}$ \\
\hline
\end{tabular}

\begin{tabular}{|c|c|}
\hline Lobbies & $\begin{array}{l}\text { The lobby also serves as an instrument for } \\
\text { environmental interpretation, because this } \\
\text { is where the tourist comes into contact } \\
\text { with the place visited. In this space, the } \\
\text { story and the importance of the property } \\
\text { can be told. It should be well designed so } \\
\text { that everyone has access and is well re- }\end{array}$ \\
\hline Signs & $\begin{array}{l}\text { The use of signs is important for visitors, } \\
\text { as they enable the tourist to reach the } \\
\text { place more easily. Signs should be eye- } \\
\text { catching, and made from weather- }\end{array}$ \\
\hline $\begin{array}{l}\text { S e I f - } \\
\text { guided } \\
\text { trails }\end{array}$ & $\begin{array}{l}\text { The visitor experiences the place without } \\
\text { the presence of the guide, supported by } \\
\text { printed material or audio. These trails }\end{array}$ \\
\hline $\begin{array}{l}\text { Guided } \\
\text { trails }\end{array}$ & $\begin{array}{l}\text { On guided trails, the visitor can have an } \\
\text { experience of exchange with the interpret- } \\
\text { er. The guide should be attentive and } \\
\text { should be able to translate the information } \\
\text { so that the tourist becomes involved in the }\end{array}$ \\
\hline
\end{tabular}

Source: Elaborated based on Ambiental (2002)

Thus, interpretation helps enrich this visitor's involvement with the heritage, and provided with the necessary tools, the tourist can assimilate and expand his or her knowledge in relation to the visited environment. In the following section, we present the methodological choices used for this discussion in relation to the Santa Barbara Chapel in Ponta Grossa, Paraná.

\section{Metodology}

In terms of methodology, this is a descriptive and qualitative study. According to Fontelles et al. (2009), descriptive research only observes, describes and records a particular fact or sample, while the qualitative approach describes, compares and interprets without considering numerical data.

In the elaboration of the theoretical framework, some of the information was obtained through articles published on the internet, using the search engines Scielo 
and Google Scholar, and books available on the internet. For this purpose, we used keywords such as environmental interpretation and heritage interpretation, thus achieving results for interpretation in built and natural places.

For the data collection, primary and secondary data were sought. According to Fontelles et al. (2009), primary data are "sources whose origin dates back to the time of research, not yet analyzed, such as literary texts and documents", and secondary data are "sources whose written works are based on the primary source, such as analysis, expansion and comparison of information". Secondary data were obtained by documentary analysis, conducting research at the "Casa da Memoria" and the Campos Gerais Museum, and for the primary data, on-site observation was used.

According to Zanelli (2002), observation situates the researcher in the scenario, leading him or her to understand the complexity of the environment and thus, allowing a more competent dialogue. In the preparation of the diagnosis, a field research was carried out in July 2018 , to obtain information and images of the place and the property, as well as the route to the place. Taking into account the aspects observed in the diagnostic data, and based on the theoretical framework, some possibilities were proposed that could be implemented at the Santa Barbara Chapel.

\section{RESULTS AND DISCUSSION ABOUT THE STUDY SITE}

The history of the Santa Barbara Chapel begins in the colonial period, in 1704, when those who offered to "serve the King and the Crown" could acquire land in the region, provided they used it for cattle farming. Captain General Pedro Taques de Almeida obtained land for himself and his children that extended from the "Jaguaricatu and Lapó rivers and the stops they called Itaiacoca" (Holzmann, 1975). During the D. Fernando Martins and Lencastre Government, the Captain General's son, José Gois de Morais, requested land between the Pitangui River and Itaiacoca, and on his father's death in 1713, acquired more land for Carambeí. Although he enriched himself with cattle farming, in the lands of Rio Verde, Itaiacoca, Pitangui, Carambeí and São João, years later, he donated his lands from Itaiacoca and Pitangui to the Company of Jesus. This was the company that in 1707 had built, with the owner's permission, a small mud chapel in honor of Santa Barbara (Holzmann, 1975).

Saint Barbara was the daughter of Irneria and Dioscuro, a nobleman who worked as an employee of the thirdcentury Diocletian emperor in Nicomedia (now known as İzmit, Turkey). With the rise of Christianity, Barbara converted to Christianity and became devoutly religious, but her father was against it and filed an arrest warrant against her daughter. She was whipped, but had her wounds miraculously healed. The judge, not believing what had happened, ordered her to be tortured by fire, but those wounds were also healed by divine grace. The father, unable to accept the events, asked for permission to take his daughter's life himself, and with a sword, pierced her neck. One day he went to the hill where he had killed Barbara, and saw that ground was covered with flowers. At that moment, a bolt of lightning struck him on the chest. For this reason, Santa Barbara is invoked in lightning and thunderstorms, and is the patron saint of artillerymen, miners, and those who work with explosives (Tommasi, 2003).

There are indications that in 1728 , there was an oratory on the site, and a chapel was later built there (Fernandes, 2003) (figure 1).

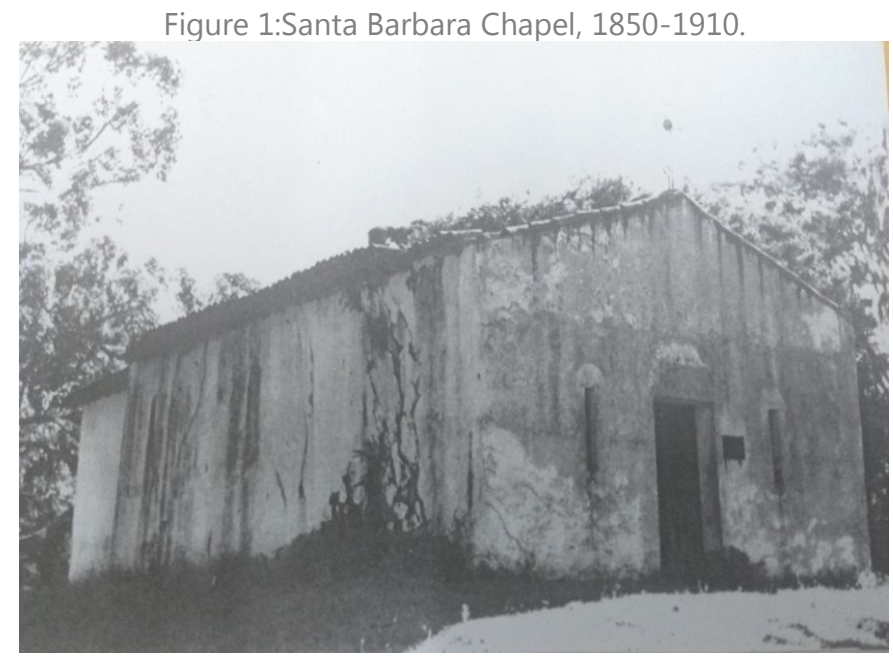

Source: Campos Gerais Museum (2018) 
According to Holzmann (1975, p. 17), the chapel was built in 1823: "The Jesuits had already built a chapel on the same site, beside a small stream called Legeadinho. It was a crude wooden house, next to an open shelter, covered with shingles, which gave it the name "House of Tiles". Here, the Jesuit missionaries would met with passing travelers or residents of the neighborhood, as this is "Casa da Telha", the closest point to the Santa Barbara chapel, on the Pitangui farm."

According to Chamma (2007, p. 48) the chapel was built after the death of Ana Siqueira Mendonça's husband, owner of the Cambijú Farm, who was buried in the cemetery of the oratory: "Having made a promise, this farmer had a larger chapel built in place of the oratory (1729). With walls of pestle mud, roof of tablets, later replaced by gouging tiles, brought from Sao Paulo on the back of donkeys by drovers. The image of Saint Barbara and other sacred objects were kept in the new chapel, blessed by the Jesuits".

The Pitangui and Itaiacoca lands returned to the Portuguese crown in 1773, with the expulsion of the Jesuits from Portugal. Pope Clement XIV dissipated the Company of Jesus, handing over its properties to D. Manoel, Bishop of St. Paul (Holzmann, 1975). With the property confiscated by the Crown, Pitangui Farm was vacated, being left without slaves, animals and plantations (Fernandes, 2003). According to Fernandes (2003) in 1798, the person in charge of the interests of the Crown in the Pitangui Farm was Corporal Francisco Pedroso de Abreu.

According to Chamma (2007, p. 49), the Jesuits in the region came to free the employees who worked on the farm, and took the opportunity to take the hidden riches. "Today it is proven that the religious obtained a lot of gold and diamonds in this region and at certain points on the Tibagi River, for this reason, for a long time, people were boring holes around the Santa Barbara chapel, its walls and the ground where the temple is built" (Chamma, 2007, p. 49).

The Bishop intended to raise the landing of Iapó to the Parish of Sant'Ana in order to increase trade, which over time, would bring new residents to the region. The Parish of Sant'Ana do Iapó created a detour in the cattle drovers' route so that it passed by the Cambijú and Itaiacoca farms, forcing them to stay overnight at Capão de Ponta Grossa (Holzmann, 1975). For Chamma (2007), with the arrival of the Bandeirantes, the region of Campos Gerais became known, and with the arrival of the drovers, routes were opened that marked the start of the village. The drovers who passed here continued on to Carambeí, Tronco and Lageado.(Holzmann, 1975).

With regional representatives Miguel Ferreira CarvaIhais and his brother-in-law Domingos Ferreira Pinto, the people needed a cemetery and a temple, as the Santa Barbara chapel, and its cemetery, was far away, and the paths turned to west. There was no longer a resident priest and religious services were only occasionally performed. So Miguel Ferreira Carvalhais asked Bishop D. Manoel to perform weddings and burials at a headquarters outside the village. The vicar of Vila de Castro, Joaquim de Almeida Leite, began to baptize and marry people in private oratories on the farms, and to facilitate this work, an altar to Mrs. Sant'Ana was built in the house of Domingos Ferreira Pinto, which was closer, leading residents to attend the Holy Offices (Holzmann, 1975).

At the same time, the residents wanted the region to be elevated to a parish, for which Domingos Ferreira Pinto, Miguel Ferreira Carvalhais and others, signed a petition making demands such as: the number of residents ; a walled chapel; a stipend for the parish priests; etc. To remedy the lack of a chapel, the altar of Sant'Ana was moved to the "Tile House" that served as a landing place for the drovers. Once these demands had been met, a new petition was sent out, and on September 15, 1823, Ponta Grossa near Jaguariaíva became a parish. (Holzmann, 1975).

Pitangui Farm, which currently belongs to the Carraro family, is a private property where the chapel and the family's other businesses are located (Figure 2). It is 500 bushels in size (Polon \& Santos, 2005). To reach the chapel, one must use the Arichernes Carlos Gobbo 
highway, then turn left where there is a tourist sign over the São Jorge River waterfall, then turn left again where a sign indicating the Santa Café is (Figure 3) which leads to a gate. The route is $16 \mathrm{~km}$ from the center of the city of Ponta Grossa to the site, but there are no specific signs indicating the location of the chapel. It should be noted that on the website of Ponta Grossa City Hall, there is a guide on how to reach the site, and the information that it is necessary to ask the farm caretaker for the key before visiting.

The chapel space, situated within the property, is surrounded and delimited by a garden. The chapel is hidden behind some old trees and it is not visible from the small gate. Only after entering and following the path we can see the chapel, which is built on a raised mound; we see some steps leading to the door, as shown in Figure 4. The dirt track along which the visitor walks is lined with flowering shrubs.

Upon entering this "reserved" area, the visitor can enjoy the calm of the place. The chapel has two small windows on each side, a single door at the front, and a wooden door on each side. The structure of the chapel, as seen from the outside, has tiles that are deteriorating. The paintings on the side and back walls have also deteriorated over time.

Figure 2: Location of the Santa Barbara Chapel

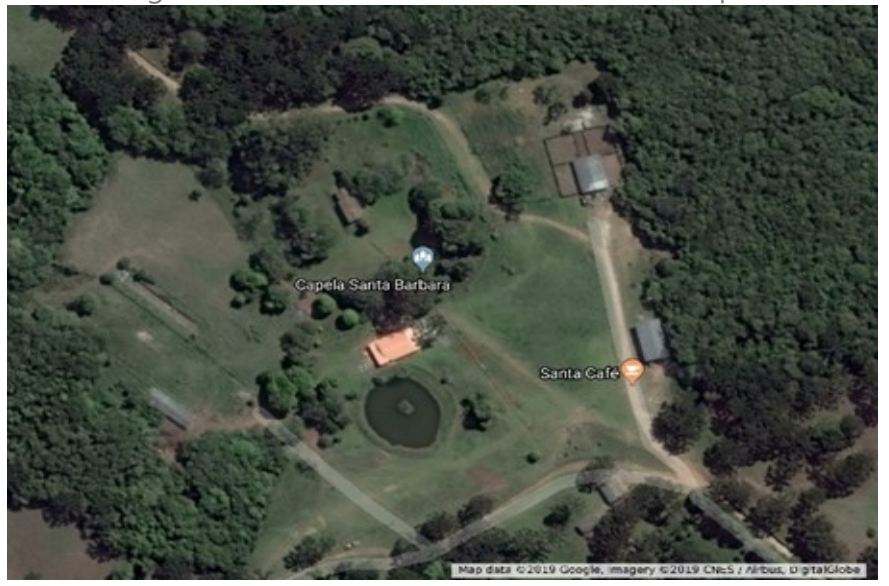

Source: (Google Maps, 2019).

Inside the chapel there are benches, an altar up ahead and a confessional box. There are some images of
Figure 3: Signs for Santa Café and São Jorge waterfall

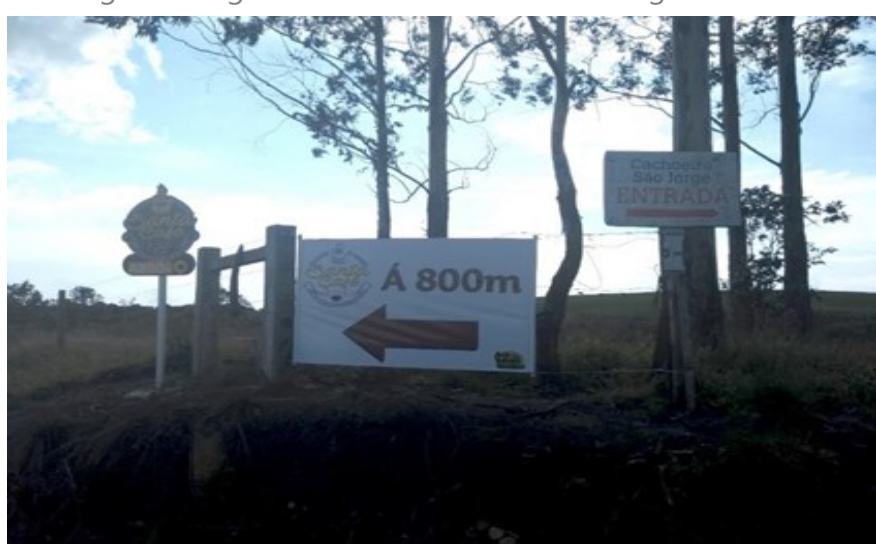

Source: Research data (2018).

saints, and some artificial flowers behind the altar, on top of which there is a bible, a candle and a wooden bowl. As sources of information, we can see a presence book on the altar, and an explanatory panel with images (Figure 5) and a history of the chapel (Figure 6). There is also the pulpit, an old, worn bell, two carved wooden fonts, and an image of Saint Barbara, as described by Oliveira (1963).

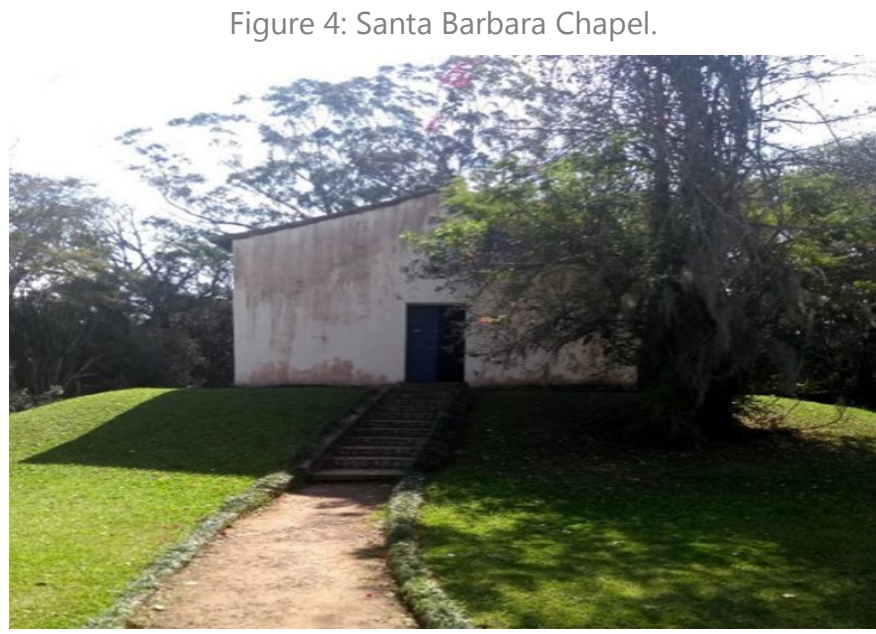

Source: Research data (2018).

On the walls, we can see the first structure before the renovation, carried out in 1973 by Nestor Carraro to help preserve the building, a wooden wall was made, which no longer exists, both in front and behind the chapel, and a new floor was laid, as the old one was in poor condition (Ponta Grossa, 2011). According to Chamma (2007) the reform that took place under the Mayor Cyro Martins government almost obliterated the colonial style of the Jesuits, and the last restoration, carried out in 2003, confirmed the existence of a cemetery there. A new restoration is now needed, as the 
walls have cracks (Figure 7), the ceiling arch paint along with the wooden floor is in good condition, but the paint on the walls, both outside and inside, is badly deteriorated, as shown in figure 8.

As you walk along a dirt path on the left at the entrance, you can look at the old wall that is still standing, but with a sign warning of the danger of approaching it.

Figure 5: Interpretative panel with images and empty space.

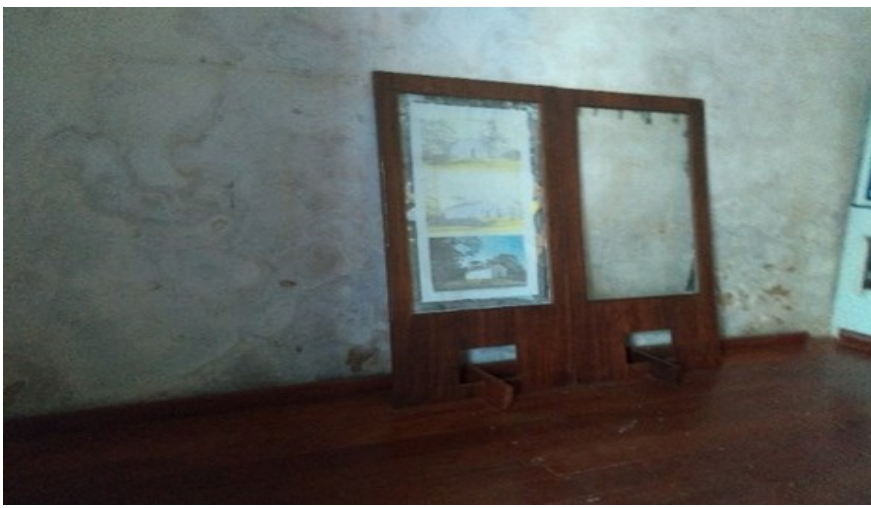

Source: Research data (2018).

Figure 6: Interpretative panel showing the history of the chapel.

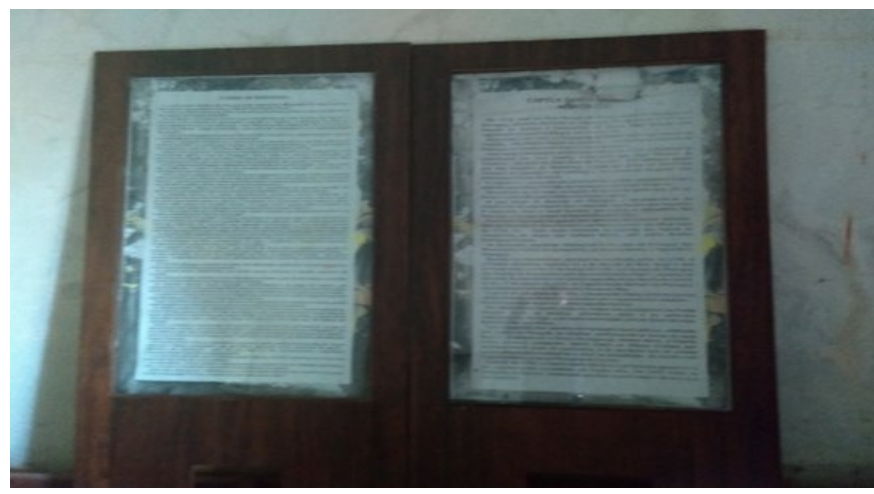

Source: Research data (2018)

Outside the chapel there are garbage cans, benches, lamps, signs, a lamppost and a small courtyard with a stone pavement and trimmed grass. Behind the chapel there are some trees and a large space with tall grass, surrounded by a wire fence.

POSSIBILITIES OF ENVIRONMENTAL INTERPRETATION AT THE SANTA BARBARA

\section{CHAPEL}

Environmental interpretation can be considered as a tool to promote understanding the space when visiting a heritage site, whether a building or a conservation unit. As Delgado (2013, p. 302) points out, interpretation of heritage should be "a planned and conscious

Figure 7: Cracks on the inner walls.

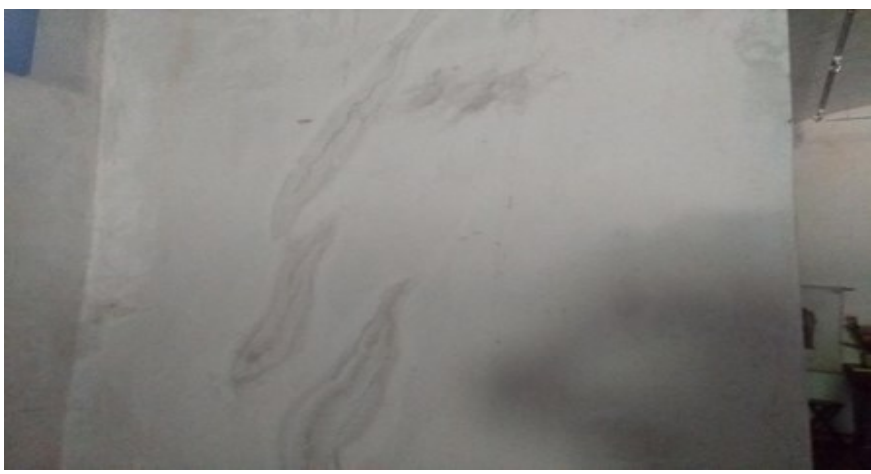

Source: Research data (2018).

Figure 8: Picture of the confessional and in detail, the deteriorated paint on the wall.

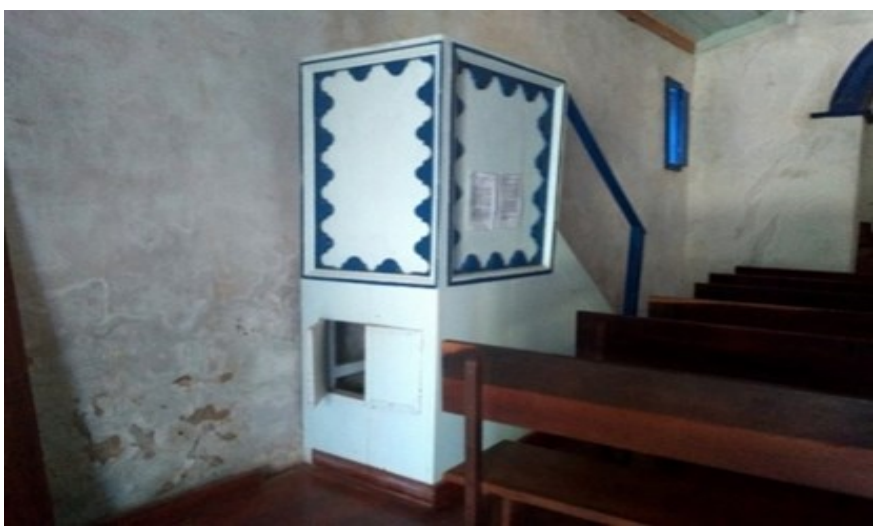

Source: Research data (2018)

way of directing messages, designed to give people significant knowledge about their heritage so that they become its protectors and defenders."

Although there is an informative panel (figures 5 and 6), it needs improvement and repair. A panel is needed that can convey information for the visitor in a way that is readable and attractive. In this regard, Murta \& Albano (2002) precisely details what an interpretive panel should look like: the panel should be made from sturdy materials, its height should be accessible to both adults and children, and it should be placed in a position that does not disturb the view or appearance of the heritage. Thus, the panel that currently exists in the chapel could be optimized with the instructions that the authors propose. 
The space does not yet have a specialized guide (interpreter) to greet the public and explain the local history. A guide would enhance the visitors' experience, and the signs would help further reinforce the history already presented. Another important item in relation to interpretation is the trails, which may be a necessary resource in this heritage. Ambiental (2002) states that for the implementation of trails at the site, it must present variation in the diversity of elements during the course. Surrounding the site, comprising part of its area and complementing its history, there are various elements such as the old wall, the burial site, and even the natural elements like the old trees. Trails present another opportunity for visitor to learn more about the history of the property, the town, its former Christian congregations, and the natural elements, among other themes. For thematic adaption, trails with guides/ interpreters are proposed, but a self-guided trail, with the support of panels or printed maps/leaflets, may be an alternative.

The guide/interpreter could simply explain the history of the chapel and relate it to the context of the city; or more detailed lectures could be given, for adults, and puppet theaters for the children. Students visiting the site on school trips could use the outside space (Figure 9) for recreational activities. Other activities, such as storytelling, puzzles, coloring, memory games, among others, could also take place at the site. All proposed activities could include heritage elements in their preparation.

A little farther from the chapel, there is also an outdoor courtyard that can be used for various activities, such as rest, or picnics, while contemplating the landscape. The many trees provide shade for most of the day, and visitors can make use of the benches there.

Notably, not all schools have trips to religious sites, and there is no information about this type of visitor. Therefore, new projects could be carried out by hiring a guide for school trips. Alternatively, it may be possible to include the site in existing projects, such as "Conhecendo PG" (Getting to Know Ponta Grossa) which is supported by the Ponta Grossa City Hall and
Ponta Grossa State University. This project takes students from public schools and associations to visit various locations around the city. The trips are free of charge, and take place on Tuesdays and Thursdays, always with monitors. The chapel could be included in the religious itinerary that takes in the Sant'Ana Cathedral, the "Casa do Divino", and the Resurrection Monastery, or trails could be created that take advantage of the area's nature and the cultural heritage in a more logistically interesting way. School trips to the site would be by appointment only, so that the guide would only need to be at the chapel during those times.

Another relevant factor that does not currently exist at the site is signposting. There is no sign outside the property indicating the location of the Chapel. Erecting signs outside the chapel is essential, to show where it is located and facilitate access. Signs are very important in tourism, as they help tourists find their way around. One of the main functions of the signs is to help visitors locate themselves on the map, and having continuity of signs provides them with a navigation route from a given location. The signs would need to be made of durable materials, to ensure that they cannot be damaged by the weather, or by vandals (Murta \& Albano, 2002).

The interpretive signs within the immediate area around the site are only warning signs about venomous animals (figure 10), and about an ancient crumbling wall (Figure 11).

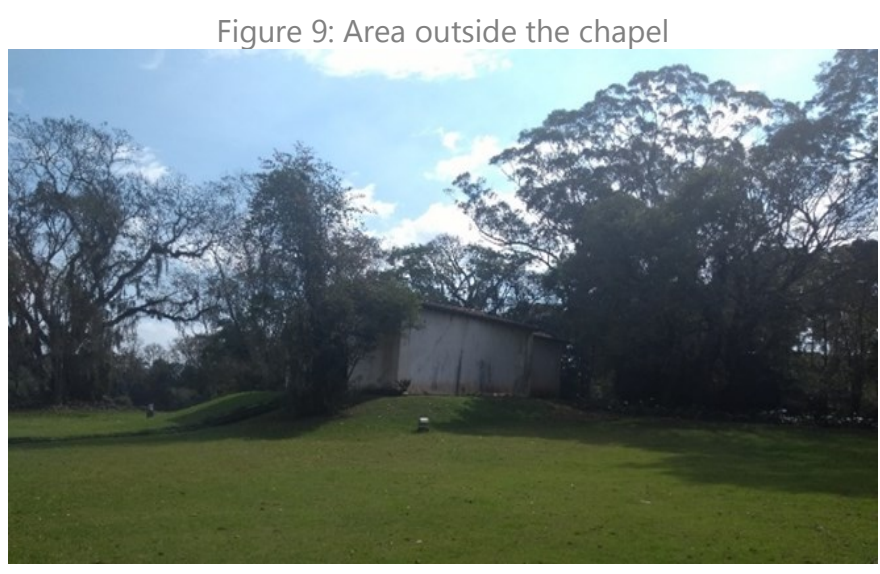

Source: Research data (2018) 
Outdoor signs should be made from weather-resistant material, and should not harm the appearance of the place. Reinforced concrete signs are a good option for this type of site, where the climate is very humid due to the many trees, as they would be easier to maintain than wooden ones. The authors of Ambiental (2002) state that in a humid climate, signs made from wood or steel signs suffer from rotting or corrosion.

\section{PRACTICAL IMPLICATIONS OF THE RESE-}

\section{$\mathrm{ARCH}$}

In the tourism literature, interpretation is usually related to educational tourism, predominantly in the natural environment. However, it can also be harnessed to make the experience more interesting (and memorable) and can be applied in many different fields.

Figure 10: Warning sign (venomous animals).

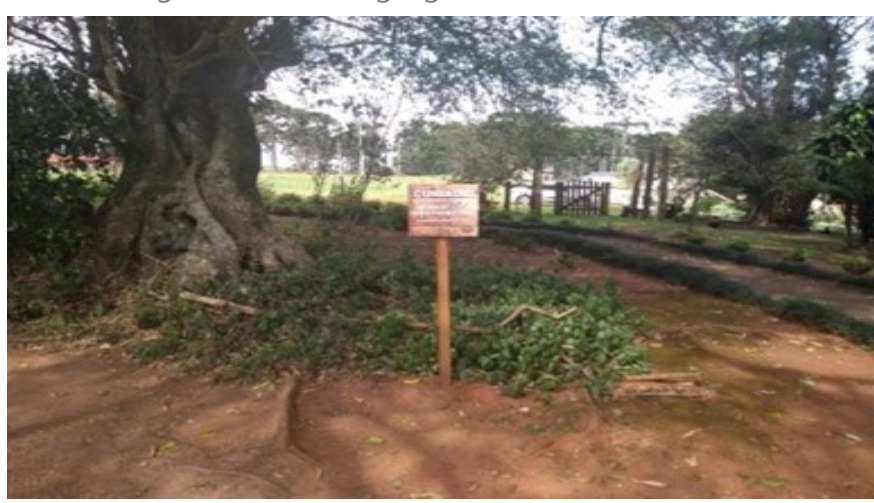

Source: Research data (2018)

Figure 11: Warning sign (caution).

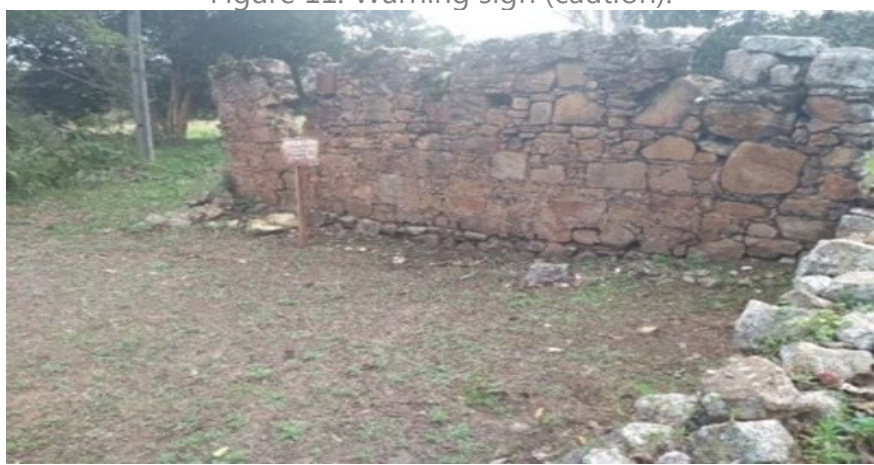

Source: Research Data (2018)

The case studied in this research is a religious cultural heritage and is also inserted in a rural environment. Suggestions were presented for the application of both internal and external interpretation of the building and surrounding area. As the construction is relatively simple, telling its story and its importance in an instructive and pleasurable way could motivate tourists and residents to visit the chapel.

It is emphasized that the knowledge passed on can also help promote its preservation and valorization. Guidemediated alternatives, as well as self-guided alternatives, may be of interest for the site. However, before implementation such alternatives, a detailed feasibility study needs to be carried out, analyzing the costs, competing sites, best times to visit, etc. It is understood that creating different interpretation alternatives can also encourage visitors to return.

In the specific case, there is also support equipment that can be the starting or closing point of any interpretative proposal. There is a coffee shop, called the Santa Café, which is owned by the family that owns the land. According to the owner, the income from this coffee shop helps to maintain the Santa Barbara Chapel. This close relationship between the coffee shop and the heritage site could be explored, perhaps by raising awareness of the history among visitors to the coffee shop, or by offering food at the site itself, such as picnics while enjoying the scenic beauty around the chapel. Or issues such as the costs of maintaining a heritage site, location could be highlighted at the site, encouraging visitors to spend at the coffee shop to help fund this effort.

Properly applied interpretation at historical sites of interest - not only at the chapel but at any natural or cultural heritage, -- can give visitors a more pleasant experience of visiting the site. Environmental interpretation should be focused on the visitor's experience, involving the senses and meanings can make the visit more enjoyable. Some of the environmental interpretation tools mentioned above, such as signboards and panels, which are commonly used in conservation units, could be used here to give information about the history of the chapel and the region's past.

Discussions about the chapel would help others seeking to learn how environmental interpretation can 
be used at a religious heritage site, or other type of property with tourism potential. They would also encouraging the implementation of interpretation tools in practice, to be carried out with the support of research to examine the costs, visual impact, and other aspects.

\section{FINAL CONSIDERATIONS}

The overall objective of this work is to discuss the potential use of environmental interpretation at the Santa Barbara Chapel. Its specific objectives are: to carry out a feasibility study of the site as a tourist attraction; to verify the applications of environmental interpretation; and to suggest actions of environmental interpretation that can be performed at the site, focusing on the appreciation of its history. This study was developed through bibliographic research, document analysis, diagnosis through observation, proposals resulting from this observation, and the use of other authors as theoretical background.

Several tools for environmental interpretation were found to be practicable for use in and around the chapel. It is concluded that environmental interpretation at the Santa Barbara Chapel could enhance its potential and leverage the visitors' experience. It could also contribute to the preservation and enhancement of the local history.

In addition to the use of environmental interpretation, the chapel could be advertised by the project "Conhecendo PG", which makes trips for schools and institutions to various attractions of the city. Besides being free of charge, it would bring benefits on both sides, both for the chapel, by publicizing it more, and for the visitors, due to its cultural value. However, a feasibility study would be needed, looking at distances visitors would need to travel between sites to see whether it can be included in the itineraries.

As a limitation of the research, it is pointed out that no cost analysis of the proposed changes was carried out to determine their feasibility. This could be a theme for future studies, examining the investments needed to apply the interpretation tools in this environment. Ano- ther suggestion would be a survey of the demand, to gauge interest in the chapel among residents and tourists, and how this could be improved by installing the interpretation tools.

\section{REFERENCES}

Alencar, R. (2013). A geodiversidade da Ilha de Santa Catarina: explorando seu valor didático no 6 o ano do Ensino Fundamental. 227 f. Dissertação (Mestrado) - Curso de Geografia, Centro de Ciências Humanas, Universidade Federal de Santa Catarina, Florianópolis.

Beltrão, L.M.V; Gomes, P.F.; Pereira Júnior, S.; Bondan, J.R.; Vargas, A.J.; Alexandre, G.C. (2018). A abordagem das geociências nos PCNs e nos Planos de Curso do 6o ano da Rede Municipal de Ensino de Jacinto Machado/SC: uma contribuição para a geoeducação no território do Projeto Geoparque Caminhos dos Cânions do Sul. Anais do VII Simpósio de Integração Científica e Tecnológica do SulCatarinen

Ambiental, Grupo Temático De Interpretação. (2002) Manual de Introdução à Interpretação Ambiental. Belo Horizonte: Projeto Doces Matas.

Azevedo, F. F., Figueiredo, S. J. de L., Nóbrega, W. R. de M., \& Maranhão, C. H. (Org.). (2013) Turismo Em Foco. Belém: NAEA/UFPA.

Biesek, A. S. (2004) Turismo e interpretação do patrimônio cultural: São Miguel Das Missões - Rio Grande Do Sul - Brasil. Tese (Mestrado em Turismo) - Universidade De Caxias Do Sul - UCS, Rio Grande Do Sul. 214f. Available at: <https:// repositorio.ucs.br/handle/11338/224>. Accessed on: 19 Apr. 2019

Chamma, G. V. F. (2007). Campo Gerais: Uma Outra História. Santa María: Pallotti.

Chaverri, A. (1988): Los Senderos Naturales: ¿Qué Son? Catie, Costa Rica. 15 P.

Delgado, A. B., \& Pazos, A. (2013) Interpretação Do Patrimônio, Turismo E Gestão De Áreas Protegidas: Algumas Aproximações. Turismo e Sociedade, 6 (2), p.300-323. Available at: <https://revistas.ufpr.br/turismo/article/ view/31930/20364>. Accessed on: 19 Apr. 2019. Doi: http://dx.doi.org/10.5380/tes.v6i2.31930.

Fernandes, J. C. (2003). Das Colinas Do Pitangui. Ponta Grossa: Editora Gráfica Planeta Ltda.

Florêncio, S. R. R. et al (2016). Educação Patrimonial: Inventários Participativos. Instituto Do Patrimônio Histórico E Artístico Nacional. Brasília: IPHAN.

Fontelles, M. J., Simões, M. G., Farias, S. H., \& Fontelles R. G. S. (2009). Metodologia Da Pesquisa Científica: Diretrizes Para A Elaboração De Um Protocolo De Pesquisa. Rev. para. Med 23 (3), Jul-Sep. 
Holzmann, G. V. F., Soares, O., \& Requião, R. (1975) História De Ponta Grossa. Ponta Grossa: Edição Histórica.

IPHAN. (2014). Bens Tombados. Brasília: Instituto Do Patrimônio Histórico E Artístico Nacional. Available at: <http:// portal.iphan.gov.br/pagina/detalhes/126>. Accessed on: 19 Apr. 2019.

Lemos, A. I. G. (Org.). (1999). Turismo: Impactos Ambientais. 2. Ed. São Paulo: Hucitec.

Machado, N. G., Devitte, N., Schneider, P. \& Kreutz, M. R. (2017) Educação Patrimonial: Relações Ambientais E Culturais. Revista Arqueologia Pública, 11 (1), p. 87-105, Jul. 2017. Available at: <https://periodicos.sbu.unicamp.br/ojs/ index.php/rap/article/view/8647933/16259>. Accessed on: 19 Abr. 2019. Doi: https://doi.org/10.20396/ rap.v11i1.8647933.

Mckercher, B. (2002). Turismo De Natureza: Planejamento E Sustentabilidade. São Paulo: Contexto.

Medeiros, D., \& Haydu, V. (2018). Interpretação Ambiental À Luz Dos Princípios Da Análise Do Comportamento: Contribuições Para Educação Ambiental. Perspectivas Em Análise Do Comportamento, 9(1), p. 43-59. Doi: https:// doi.org/10.18761/pac.2017.012

Moreira, J. C. (2014). Geoturismo e Interpretação Ambiental. 1. Ed. Ponta Grossa: Editora UEPG.

Murta, S. M. \& Albano, C. (Org.). (2002). Interpretar O Patrimônio: Um Exercício Do Olhar. 1. Ed. Belo Horizonte: UFMG.

Oliveira, I. F. (1963). Álbum De Ponta Grossa. Ponta Grossa: [S.N.].

Pires, P. D. S. (2002). Dimensões Do Ecoturismo. São Paulo: Senac São Paulo.

Polon, S. A. M., \& Santos, L.M. R. dos. (2005). Memória e História: Capela Santa Bárbara do Pitangui. In. VI Jornada Do Histedbr. Anais [...]. Faculdade De Educação - Unicamp. Available at: $\quad$ <http://www.histedbr.fe.unicamp.br/ acer_histedbr/jornada/jornada6/resumos/769.htm>. Accessed on: 19 Apr. 2019.

Ponta Grossa. P. M. (2001). Turismo Religioso: Capela Conta Trajetória Dos Jesuítas Na Região. Available at: < http:// www.pontagrossa.pr.gov.br/node/10105 >. Accessed on: 01 Sep. 2018.

Silva, D. M. \& Júnior, Á. L. (2010). A relação entre trilhas interpretativas, interpretação ambiental e educação ambiental, e a importância das espécies arbóreas para essas atividades.In. Anais Do II Simpósio Nacional De Ensino De Ciência E Tecnologia. Ponta Grossa: Utfpr. Available at: <http:// www.sinect.com.br/anais2010/>. Accessed on: 29 Oct. 2018.

Siqueira, L. F. (2004). Trilhas Interpretativas: Uma Vertente Responsável Do (Eco) Turismo. Caderno Virtual De Turismo, 4 (4), p.79-87. Available at: <http://www.ivt.coppe.ufrj.br/ caderno/index.php/caderno/article/view/72> Accessed on: 13 Apr. 2019.

Soifer, J. (2005). Empreender Turismo e Ecoturismo. Rio De Janeiro: Qualitymark.
Souza, K. (2010). A Interpretação Ambiental Na Conservação Do Patrimônio Cultural: O Caso Do Arqueosítiomusealizado Da (Real) Fábrica De Neve De Montejunto, Portugal . Revista Cpc, (10), 89-115. https://doi.org/10.11606/issn.19804466.v0i10p89-115. Accessed: 19abr. 2019.

Tilden, F. (1977). Interpreting Our Heritage; 3o Edition. The University Of North Carolina Press.

Tilden, F. (2006). La Interpretación De Nuestro Patrimonio. Tradução De Pablo Salas Rojas. 1. Ed. Sevilla: Asociación Para La Interpretación Del Patrimonio.

Tommasi, T. (2003) Santa Bárbara. Available at: <http:// www.npdbrasil.com.br/religiao/santa_barbara.htm>. Accessed on: 14 Set. 2018

Turismo, F. M. (2019). Capela Santa Bárbara. Available at: <http:// www.pontagrossa.pr.gov.br/capela-santa-barbara>. Accessed on: 18 Aug. 2018

Unit, Project Coordinating. Environmental Interpretation Manual For Protected Areas In The Mesoamerican Barrier Reef System Region. 2005. Available at: < Https://www.cbd.int/ doc/pa/tools/environmental\%20interpretation\% 20 manual\%20for\%20protected\%20areas\%20in\%20the\% 20mbrs.pdf>. Accessed on: 18 Ago. 2018.

Vasconcellos, J.M.O. (1998). Avaliação Da Visitação Pública E Da Eficiência De Diferentes Tipos De Trilhas Interpretativas No Parque Estadual Pico Do Marumbi E Reserva Natural Salto Morato - PR. 139 Fls. Tese (Doutorado Em Ciências Florestais) - Universidade Federal Do Paraná, Curitiba. 1998. Available at : $\quad$ https://acervodigital.ufpr.br/ handle/1884/25417> Accessed on: 11 Nov. 2018.

Zanelli, J. C. (2002). Pesquisa Qualitativa Em Estudos Da Gestão De Pessoas. Estudos De Psicologia, 7 (número especial), p. 79 -88 . 
C2019 autores. Publicado por Univali Esse artigo é de livre acesso sob a licença 